Mournals
RARKETING AND BRANDING $\begin{gathered}\text { INDUSTRIAL } \\ \text { MANAGEMENT } \\ \text { INSTITUTE }\end{gathered}$

\title{
The idea of new product development in modern medical Polish enterprises
}

\author{
Anna Dziadkiewicz ${ }^{1 *}$, Joanna Nieżurawska ${ }^{2}$ \\ ${ }^{1}$ Marketing Department, Faculty of Management, University of Gdansk \\ ${ }^{2}$ Management Department, Faculty of Finance and Management, Torun School of Banking
}

Keywords:

Empowerment, Diffusion of Innovation, New Product Development, NPD Model, Customer-Orientated Strategy

Correspondence: a.dziadkiewicz@hotmail.com

\begin{abstract}
The success of launching of a new product on the market depends largely on the activities that are undertaken by the manufacturer. The brand, the positive image of the manufacturer, quality, innovation, technology, the low cost of manufacturing, the well-balanced product price, and the degree of fulfilment of customer expectations all determines the success of a business. The traditional New Product Development (NPD) model in which companies are entirely responsible for producing new product ideas and for determining which products should finally be marketed is progressively being challenged by academics and practitioners alike working in the field of innovation management. The main aim of this article is to present the traditional NPD model and the different dimensions of the NPD strategy. In this article, the authors provide a short empirical study to explore the issue of how the NPD process is run in Polish private medical businesses.
\end{abstract}

(C)AIMI Journals

\section{Introduction}

Launching of a new product is a challenge that provides success and profits not only for a certain year, but also ensures a long-term survival. Thus, it is a project that should be reliable, thoughtful, examined, and tested to give an assurance that the manufacturer has the confidence that all the necessary procedures have been performed to check whether the product will sell well or not.

The whole plan of launching of a new product requires a number of research and cognitive activities, aimed at defining the market absorption, the demand for the product, the choice of the optimal time of the marketing campaign, a reliable cost and risk estimation, etc. Many companies do not focus their attention on unsuccessful business symptoms, so the final result 
is that purchasers are completely uninterested in the designed services and products.

However, it is necessary to start with defining a new product. Regardless of the culture, consumers always react strongly to the word "innovation". Nowadays, even if the word is only displayed on a shop shelf, it can attract consumers. Simultaneously, according the Roger's model, consumers keep new products at a distance, but in time, when they notice the products can fulfil their wants, they buy them.

The main aim of the strategy of launching a product on the market is to minimize the investment risk by setting goals at each stage of the NPD process. Generally, there are a few steps in the process of new products' planning which include the idea of a new product and its assessment, marketing analysis, technological capabilities to produce the product, market research, and transformation of ideas into a prototype which is then subjected to testing, commercialization, real product launch, and acceptance (or not) of a new product by consumers.

Strategic innovation theories are market-orientated. They focus on customers' needs and on the demand that stimulates innovations. Unquestionably, the present companies are aware of the fact that working systematically on business strategies and innovation is still the most important factor of company's development.

In addition to working on the current strategy, it is worth to remember to observe the changing consumers' attitudes, trends, and differences in intercultural wants which will allow to use an appropriate customer-orientated method of management. Market research that allows gaining information about the innovative solutions used by competitors is also necessary. The starting point is creativity in development of the existing products, processes, marketing, and organizational structures or a mixture of these elements.

There are some popular methods used in the building of the NPD strategy (Kukian, 2012), namely brain storming, Delphi method, critical evaluation and analysis, portfolio analysis, Gordon technique, algorithm of the invention, morphological method, Polay method, and transforming using the graphic symbol (optional).

The application of these methods in a rapid and complete way has become possible, e.g. thanks to its availability on the Internet. Sometimes, the product is worth presenting to a wide range of quasi-public to get to know their opinion - the method is unfortunately unreliable, especially when the target audience goes beyond average Internet users. Despite this limitation, the Internet offers another benefit - it allows to explore sincere opinions of users from around the world.

Scientific research has provided strong arguments indicating that active participation of customers in the NPD strategy allows for the development and launching of the upgraded products, as well as for the reduction of costs and risks.

The results of the research on the customer participation in the development of products have been presented by scientists like Martin Schreier from the Rotterdam School of Management, the Erasmus University and Christoph Fuchs and Martin Schreier from the Bocconi University (Fuchs \& Schreier, 2011).

\section{Rogers' Model - Diffusion of Innovation}

The theory of diffusion of innovation is worth mentioning as it explains how, why, and at 
what rate new technology and ideas spread in different cultures. The first author who has mentioned the concept of diffusion of innovation was Everett Rogers - a professor of communications studies.

Diffusion means a process of innovation absorption in newer and newer social systems (Pomykalski, 2001). This phenomenon occurs in the company or in an economy after the first successful technological or organizational use has been made when there is assimilation by other companies (Brzeziński, 2001).

After the launching of a new product, there follows a process called "learning by doing". There are a few members who take a part in it such as the manufacturer who implements innovation (improvement of innovation based on feedback); the potential purchaser (getting to know a new product in order to take a decision about a purchase); and the potential adopter (identification of the most important characteristics of the innovation, its manufacture, and launching of their own production).

Rogers (1962) claims that there are a few categories of purchasers who manifest various kinds of attitudes to innovation; those who constantly look for innovation and those who prefer the tried-and-tested products. Table 1 shows the classification of adopters.

Table 1

Classification of Adopters

\begin{tabular}{ll}
\multicolumn{1}{c}{$\begin{array}{c}\text { Adopters } \\
\text { Category }\end{array}$} & \multicolumn{1}{c}{ Definition } \\
\hline Innovators & $\begin{array}{l}2.5 \% \text { of the total population like risking and trying out innovations, they have the highest social status, financial } \\
\text { liquidity, are sociable, and have the closest contact with scientific sources and are in interaction with other innovators. } \\
\text { Financial comfort lets them to adopt those technologies that may eventually fail. }\end{array}$ \\
\hline Early Adopters & $\begin{array}{l}13.5 \% \text { of the total are leaders, they create the social opinion, and they are cautious in purchasing. Early adopters have } \\
\text { an eminent social status, financial liquidity, advanced education. Besides, they are more socially forward than late } \\
\text { adopters. In comparison with innovators, they are more cautious in their adoption choices. }\end{array}$ \\
\hline Early Adopters & $\begin{array}{l}34 \% \text { of the total start to be interested in new products earlier than average purchasers. Early majority possess above- } \\
\text { average social status, contacts with early adopters, and sometimes they hold positions of opinion leadership. }\end{array}$ \\
\hline Late Majority & $\begin{array}{l}34 \% \text { of the total is sceptics who accept the product after other customers have tried it, they possess a below-average } \\
\text { social status, little financial liquidity, and they are in association with others in late majority and early majority and } \\
\text { little opinion leadership. }\end{array}$ \\
\hline $\begin{array}{l}16 \% \text { of purchasers who are afraid of changes and who accept innovation once it has become popular and necessary. } \\
\text { The individuals in this set present little or no opinion leadership. Laggards commonly incline to focus on "tradition", } \\
\text { have the minimal social status and the lowest financial liquidity, they are the oldest among adopters and in contact } \\
\text { with only family and close friends. }\end{array}$
\end{tabular}

Rogers (1962) stated that four principal factors affect the spread of a new idea including the innovation itself, the communication channels, the time and the social system (Table 2). This process relies heavily on human capital. It is necessary to obtain adequate knowledge about the customers' needs and wants and get first to the innovators to convince them of the rightness of purchase of innovation. Diffusion demonstrates itself in different ways in various cultures and fields and is highly subjected to the type of adopters and innovation-decision process. Note, however, that the buyer may be an innovator in one area and a laggard in another one; therefore, any identification of groups based on the previous reviews and experiences should be considered only as an estimation. Table 2 presents the key elements in diffusion research. 
Table 2

The Key Elements in Diffusion Research

\begin{tabular}{ll}
\hline Element & An idea, practice, or object that is perceived as new by an individual or other unit of adoption. \\
\hline Innovation & The means by which messages get from one individual to another. \\
Communic-ation channels & Innovation-decision period is the length of time required to pass through the innovation-decision process. \\
Time & The rate of adoption is the relative speed with which an innovation is adopted by members of a social system. \\
Social System & A set of interrelated units that are engaged in joint problem solving to accomplish a common goal. \\
\hline
\end{tabular}

Rogers (1962) claimed that the decision-making process is a five-step process, namely awareness, interest, evaluation, trial, and adoption. We need to focus on the adoption process as the least explored and thus hazy. Adoption refers to the individual process describing the series of stages that one first goes through the hearing about a product and finally starts to use it. Diffusion signifies a group phenomenon that refers to a manner in which an innovation spreads. The crucial thing is the fact that an individual might reject an innovation at any time during or after the adoption process. Table 3 represents the five stages of adoption process.

Table 3

Five Stages of Adoption Process

\begin{tabular}{ll}
\hline Stage & \multicolumn{1}{c}{ Definition } \\
\hline Knowledge & $\begin{array}{l}\text { The individual is first exposed to an innovation, but lacks information related to the innovation. During this } \\
\text { phase, the individual has not yet been encouraged to discover additional information related to the innovation. }\end{array}$ \\
Persuasion & $\begin{array}{l}\text { The individual pays great attention to the innovation and diligently searches out related information/details. } \\
\text { The individual takes the notion of the change and assess the advantages/disadvantages of using the innovation } \\
\text { and determines whether to adopt or disapprove the innovation. Regarding the individualistic nature of this stage, } \\
\text { Regers states that it is the most effortful stage on which to develop empirical evidence. }\end{array}$ \\
Decision & $\begin{array}{l}\text { The individual utilize the innovation to a fluctuating degree depending on the situation. During this phase, the } \\
\text { individual also considers the practicability of the innovation and may seek for additional information about it. }\end{array}$ \\
\hline Implementation & $\begin{array}{l}\text { The individual finalizes his/her decision to resume using the innovation. This phase is both intrapersonal (may } \\
\text { bring cognitive dissonance) and interpersonal, confirmation that the group has made the right decision. }\end{array}$ \\
\hline Confirmation &
\end{tabular}

The rate of adoption of a product is determined as the approximate speed at which users adopt an innovation. It is estimated by the length of time for a specific percentage of consumers of a social system to adopt an innovation. The rule states that the individuals who first adopt an innovation require a shorter adoption time in relation to late adopters. There are a few adoption strategies. The first is used in social networks. Another strategy involves injecting an innovation into a group of individuals who would utilize the technology as well as providing positive reactions and advantages for early adopters. Rogers (1962) has also identified five factors that influence customer decisionmaking in the process of adoption or rejection of an innovation. Table 4 exhibits the five factors that influence adoption. 
Table 4

Five Factors that Influence Adoption (An Example from Apple)

\begin{tabular}{ll}
\hline Factor & \multicolumn{1}{c}{ Definition } \\
\hline Relative Advantage & $\begin{array}{l}\text { The extent of improvement of an innovation compared with the innovation over the previous generation. } \\
\text { or Windows phone? }\end{array}$ \\
& The degree of compatibility that an innovation has to be assimilated into an individual's life. \\
Compatibility & $\begin{array}{l}\text { Notice: How hard is it to integrate this into my daily life? An iPod is very easy to integrate as Steve Jobs } \\
\text { famously said "1,000 songs in your pocket". }\end{array}$ \\
Complexity or & $\begin{array}{l}\text { The extent of comprehensiveness or simplicity of the product in customers' mind (if the innovation is } \\
\text { comprehended as complex or difficult to use, an individual is unlikely to adopt it). }\end{array}$ \\
Trial ability & Notice: Touch screen interface: an iPhone is intuitive. \\
\hline & $\begin{array}{l}\text { The extent of simplicity in an exploration (if a user is able to test an innovation, they will be more likely to } \\
\text { adopt it). }\end{array}$ \\
Notice: Store experience of Apple.
\end{tabular}

According to Rogers (1962), rejection or acceptance of an innovation depends on the following factors:

The Relative Convenience of the Innovation: An innovation should provide an increase in socio-economic efficiency and be more convenient than the previous solution.

Compatibility of an Innovation: An incompatible innovation is misunderstood and irrelevant and as a result rejected. Compliance of an innovation with the existing standards, values, and experience promotes its popularizing.

Complexity of an innovation: This feature is determined by the degree of difficulty in understanding, adoption, and application of the new solution.

Severability of an Innovation: The gradual introduction or adoption of innovation.

Affordability of an innovation: The innovation is reasonable if the nature and process of its use is clear and easy to produce.

\section{Traditional New Product Development Model}

The traditional NPD model assumed that only a manufacturer was responsible for creating the idea of a new product that was being launched and for the decisions that were made inside the company. It was called a strategy of zero customer empowerment. This attitude was often questioned by both theoreticians and practitioners of business who realised in the mideighties of the twentieth century that technology-orientated strategies are not sufficient. Until that time, it was popular to prepare a certain technology and then find purchasers who were inclined to accept the company's offer.

The 80s were known as a time of madness in process improvement; so, as a result, all trial-and-error methods in the field of innovation were really expensive. The companies couldn't afford a failure, especially since failure rates reached $90 \%$, the expenditures on R\&D went widely over with a toothcomb, and the average time of the project of a new product had 
become as long as 8 years, it became obvious that it was necessary to find a new approach to innovation (Ulwick, 2009). The idea of active participation of the customer together with the manufacturer in design making, new product creation, and its implementation had consequently emerged.

The traditional new product development model in which companies are entirely responsible for producing new product ideas and determining which products should finally be marketed is progressively being challenged by innovation management academics and practitioners alike.

\section{The Role of Modern NPD: Empirical Research}

The main goal of our research is to find how the NPD process is run in Polish private medical businesses. This research project began on March 2014 and lasted till March 2015, and includes the field data on the successes and failures of over 330 medical products/services. The research has been divided into three parts, namely two exploratory surveys (158 product/services), case study validation (21 cases), and empirical testing of our model on the factors that influence the product outcome.

All the companies requested us to keep them anonymous. The duration of the interviews was counted from the moment when the respondents were asked their first questions. Almost all the interviews were recorded and transcribed except those that were done on the phone. During the phone interviews, one of us was asking questions while the other was writing the answers to the questions. We believe that no important information was lost due to the great care we took.

Before the main research, we conducted a pilot research (an audit) that lasted for 3 months. According to the previous observation of the medical private market in Poland, we have found from these studies that the success of the new medical product/service was likely to be greater under the following circumstances:

- The firm had an in-depth understanding of its customers and the medical marketplace;

- The firm marketed proficiently and committed a significant amount of its resources to selling and promoting of its successful medical products/services;

- The firm's R\&D was efficiently planned and well executed;

- The firm's R\&D, marketing and PR functions were well coordinated;

- The firm provided a high level of management support for the medical product/service from the development stage through its launch to the marketplace;

- The medical product/service had a high performance to cost ratio;

- The medical product/service significantly benefited from the firm's existing market;

- The medical product/service provided a high contribution margin to the firm;

- And, the medical market had few competing products/services.

This short list of the factors necessary to develop a successful new medical product/service is useful, but not a strong guide for managerial action. That is why we have tried to create a model of critical influences on a new medical product's development that could then be tested. Using the findings from the previous audit realized in medical institutions and the research literature as a guide, we outlined our model of the critical 
influences on the product development process. This model (Figure 1) is based on our interpretation of the process of the new product development in knowledge-based industry as a change producing activity. In the following section we will explain the significant attributes of the model followed by the hypotheses we have developed to test the influence of each of these attributes on the product outcome.

The model describes the development process in terms of organizational and external entities that influence the product outcome. There are two primary groups involved in a new product's development in medical business: R\&D and marketing \& PR. The prior (audit) research indicated that three factors relating to these functional groups influenced the product outcome.

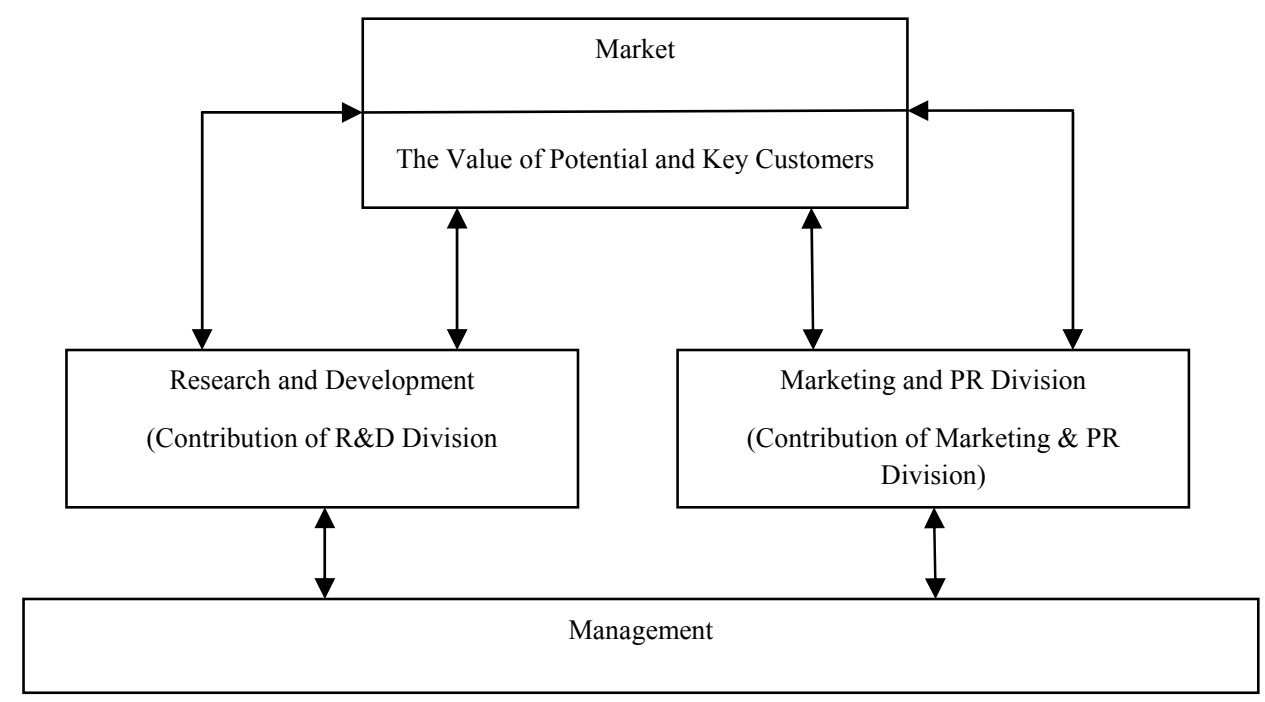

Figure 1. Model of critical elements of the NPD process

The first factor refers to the competence of the functional groups. The product success was more likely if development was conducted by a competent and skilled R\&D and marketing \& PR team. Secondly, it was important that the development process was wellplanned and capably executed. That often included assistance of a medical champion who promoted the product to senior management, to other functional groups, and to customers throughout the development and introduction cycles. Finally, successful development relies on strong communication links and cooperation between the functional groups (Dziadkiewicz \& Kłos, 2013) in order to effectively manage the transition of the product through the various design and development stages. The implicit barrier between the functional groups is shown in the model by physical divisions between the entities. Without sensible endeavor by the organization to bridge these gaps, information essential to the product's form and function are likely to be lost, especially, as the organization grows in difficulty and variety.

\section{Hypotheses}

The following hypotheses guided the study.

$\mathbf{H}_{1}: \mathrm{R} \& \mathrm{D}$ competence and management is positively related to medical product/service success and negatively related to product/service failures. 
$\mathbf{H}_{2}$ : Marketing \& PR competence and coordination is positively related to medical product/service success and negatively related to product/service failures.

$\mathbf{H}_{3}$ : General management support of the product/service development effort is positively related to product/service success and negatively related to failure.

$\mathbf{H}_{4}$ : A medical product/service providing a significant value (performance to cost) to the customer is positively related to successful products/services and negatively related to failures.

H5: Superior medical product/service is positively related to successful outcomes and negatively related to failures.

$\mathbf{H}_{6}$ : Medical products/services that build upon the firm's existing market and product competences are positively related to successes and negatively related to failures.

$\mathbf{H}_{7}$ : Weak competitive environments are positively related to medical product/service successes and negatively related to failures.

$\mathbf{H}_{\mathbf{8}}$ : Medical markets that are large and growing are positively related to successful outcomes and negatively related to failures.

Using our model of the new product development as a guide, we presented eight hypotheses that we believe they represent the key influences on the new product outcome. Our next step was to test these hypotheses in a large sample study of the product successes and failures. The objective of this final test and analysis was to confirm the significance of these hypotheses in influencing the product outcome and determining a relative importance of each of the factors.

\section{Method}

The unit of analysis for the study was a product pair, one success and one failure, and the sample consisted of 172 medical products or services. Two products or services were selected by each company that participated in the study, one product/service considered to be a success and one - a failure. The respondents were asked to choose a pair of these products that were the financial extremes. The level of a product's success and failure was assessed on a ten-point scale ranging from a major financial loss to a major profitability contributor with financial break even at its midpoint. The success and failure ratings were graphed and the results are shown in Figure 2.

It is worth mentioning that 24 of the original 172 products were later excluded because of incompleteness of the data. The final analysis included 148 innovations: 77 successful ones and 71 failures.

Following this, success and failure ratings did overlap, but for any pair of products in the sample, successes were always more financially lucrative than failures. In addition, the correlation between a success and a failure outcome was low, 0.05 , and a $t$-test of the success and failure means indicated a significant difference $(\mathrm{p}<0.001)$. The product success and failure pair within each company was developed within five years of each other and were introduced into the same or similar market. The sample distribution by market include medical devices (30\%), test, measurement, and control instruments $(22 \%)$, communication 
systems (16\%), medical components, materials, and equipment (16\%), and other (16\%). Figure 2 illustrates the innovation financial performance.

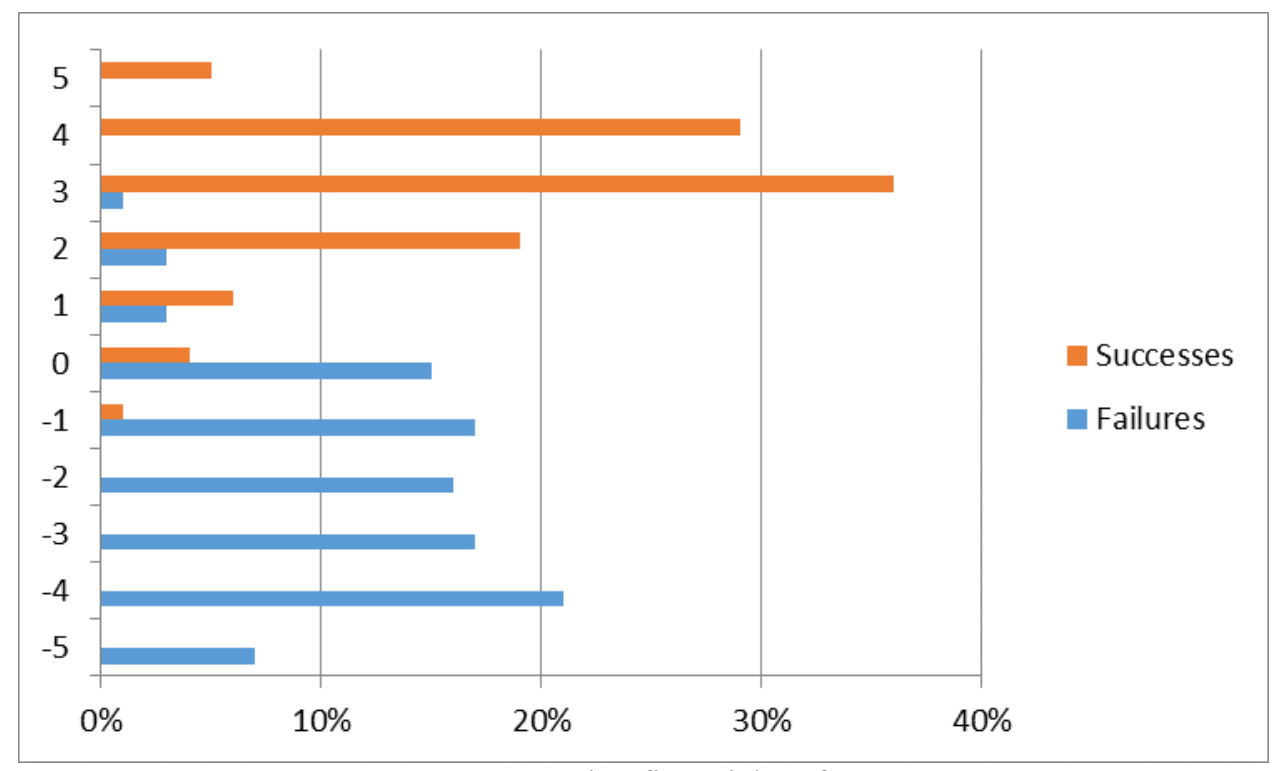

Figure 2. Innovation financial performance

The data collection was divided into three parts including background data of the respondents such as company or division; selection and description of two innovations (1 success; 1 - failure) plus evaluation of the degree of each product/service's success on a tenpoint scale; and survey consisted of 23 items, determined in the previous audit and case study work.

Following this, 23 items mentioned above provided the basis for our empirical test of the NPD process, so we decided to reduce these items to a smaller set of underlying constructs. In order to reduce the data set, we conducted SPSS exploratory factor analysis believing it would be a good description of the underlying constructs and it has resulted in an 8-factor solution.

These constructs and the items measuring each construct are shown in Table 5. The constructs' names correspond to the factor labels determined for each factor group The value for each construct was considered by calculating the numeric average of the scale values for the items in each construct (Table 5).

According to Table 5, the first construct, R\&D excellence, consisted of seven items with a scale mean for successful products of 5.74 and a failure mean of 4.11 (Tables 6 and 7). The Cronbach's alpha of the R\&D excellence scale was 0.83 . The marketing and PR competence scale had a 4.85 and 4.13 mean value for successes and failures, respectively and an internal consistency measure of 0.70 . The product value and product synergy scales each had three measures and had reliability values of 0.52 and 0.73 . Product value had a success mean of 4.87 and a failure of 3.72. The Product synergy scale had a 0.98 difference between the mean value of the success rating for the scale, 5.91, and the failure rating of 4.93. The technical performance was measured by a two-item scale with a reliability of 0.67 and the mean value of the successful products, 5.61, was greater than the unsuccessful products mean by 1.7. Table 5 
Factor Analysis Results in Medical Companies

Factor and Variable Description

Factor Loadings

R\&D Excellence

1. Products/services had superior quality and reliability.

2. Product was developed by a highly competent knowledge-based organization.

3. Product development process was well planned.

. Product was strongly supported by project management.

5. Coordination between creation and service was good.

. A clearly identified individual was an activist in promoting the product's development throughout the product development and the introduction cycle.

7. Product/service was a good match with the customer's needs.

Marketing \& PR Competence

1. Coordination between marketing \& PR and service was good.

2. Product/service was created by a highly competent knowledge-based organization.

3. Product/service was introduced by a highly competent sales and marketing organization.

Eigenvalue: 1.9

Percent of variance: 8.2

Synergy with Existing Competences

1. Product/service benefitted from its closeness to the company's existing products.

2. Product/service benefitted from its closeness to the company's existing markets.

3. Product/service benefitted from its closeness to the company's technologies.

Eigenvalue: 1.7 Percent of variance: 7.3

Superior Product/Service Performance

1. Coordination between marketing \& PR and service was good.

2. Product/service had superior service performance.

Eigenvalue: 1.5

Percent of variance: 6.7

Large and Growing Market

1. Product/service was developed for a large market.

2. Product/service was developed for a rapidly growing market.

Eigenvalue: 1.3 Percent of variance: 5.8

General Management Support

1. Product/service was strongly supported by general management.

Eigenvalue: 1.3

Percent of variance: 5.6

Weak Competitive Environment

1. Product/service was first to the market.

2. Product/service was developed for a market with few strong competitors.

Eigenvalue: 1.0

Percent of variance: 4.5

Product/Service value

1. Product/service was priced lower than competitive alternatives.

2. Product/service provided superior benefit to cost.

3. Product/service concept developed from frequent interactions between the product development team, introduction team and the customers.

Finally, the market descriptor scales, market size and growth, and weak competitive environment had reliability indexes of 0.59 and 0.53 , respectively and each were measured by two items (Table 6). The mean value for successful products using the market size and growth scale was 5.64 and the failure mean was 4.87. The competitiveness of the environment scale was similar with a success average of 5.21 and failure of 4.30 (Table 7).

Table 6 


\begin{tabular}{|c|c|c|c|c|c|c|c|c|}
\hline & \multicolumn{8}{|c|}{ Intercorrelations and Reliabilities } \\
\hline & 1 & 2 & 3 & 4 & 5 & 6 & 7 & 8 \\
\hline R\&D Excellence & 1.00 & & & & & & & \\
\hline Marketing \& PR Competence & $0.50^{* * *}$ & & & & & & & \\
\hline Product/service Value & $0.43^{* * *}$ & 0.19 & & & & & & \\
\hline Superior Product/Service Performance & $0.64 * * *$ & $0.50^{* * *}$ & $0.41 * * *$ & & & & & \\
\hline Management Support & $0.30^{* * *}$ & 0.18 & 0.16 & $0.36^{* * *}$ & & & & \\
\hline Product/Service Synergy & $0.36^{* * *}$ & $0.29 * * *$ & $0.26^{* *}$ & $0.34 * * *$ & 0.20 & & & \\
\hline Weak Competitive Environment & 0.18 & 0.11 & 0.20 & $0.22 * *$ & 0.06 & 0.13 & & \\
\hline Large \& Growing Market & $0.25 * *$ & 0.20 & 0.13 & 0.20 & 0.22 & 0.16 & $-0,08$ & \\
\hline Reliabilities & 0.83 & 0.70 & 0.52 & 0.67 & $\mathrm{x}$ & 0.73 & 0.53 & 0.59 \\
\hline
\end{tabular}

$* * \mathrm{p} \leq 0.01$

$* * * \mathrm{p} \leq 0.001$

This scale has only one question.

Table 7

Means and Standard Deviations

R\&D Excellence

Marketing \& PR Competence

Product/service Value

Superior Product/Service Performance

Management Support

Product/service Synergy

Weak Competitive Environment

Large \& Growing Market

\begin{tabular}{cccccc}
\multicolumn{2}{c}{ Success } & \multicolumn{2}{c}{ Failures } & \multicolumn{2}{c}{ Total Sample } \\
\hline Mean & SD & Mean & SD & Mean & SD \\
\hline 5.74 & 0.81 & 4.11 & 1.23 & 4.96 & 1.31 \\
4.85 & 1.30 & 4.13 & 1.37 & 4.50 & 1.38 \\
4.87 & 1.13 & 3.72 & 1.30 & 4.32 & 1.34 \\
5.61 & 1.09 & 3.91 & 1.59 & 4.79 & 1.60 \\
6.20 & 1.18 & 5.20 & 1.76 & 5.70 & 1.57 \\
5.91 & 1.12 & 4.93 & 1.48 & 5.44 & 1.39 \\
5,21 & 1.62 & 4.30 & 1.67 & 4.77 & 1.70 \\
5.64 & 1.15 & 4.87 & 1.71 & 5.27 & 1.49 \\
\hline
\end{tabular}

As it is shown in Table 8, the split half sample had very similar coefficient magnitudes and rankings compared to the full sample model. As a predictor of a success and failure outcome, the discriminant model was quite good and correctly predicted success and failure in $88 \%$ of the original samples. Similarly, the split sample predicted outcome well (Table 8 ).

Table 8

Results of Hypotheses Tests based on Discriminant Analysis

\begin{tabular}{|c|c|c|c|}
\hline \multicolumn{2}{|c|}{ Variable Description } & Structure Coefficients & $\begin{array}{c}\text { Split Sample } \\
\text { Structure Coefficients }\end{array}$ \\
\hline \multicolumn{2}{|c|}{ Excellent R\&D Organisation } & $0.80 * * *$ & $0.77 * * *$ \\
\hline \multicolumn{2}{|c|}{ Superior Product/Service Performance } & $0.64 * * *$ & $0.60 * * *$ \\
\hline \multicolumn{2}{|c|}{ Product Value } & $0.48 * * *$ & $0.44 * * *$ \\
\hline \multicolumn{2}{|c|}{ Synergy with Existing Competences } & $0.38 * * *$ & $0.48 * * *$ \\
\hline \multicolumn{2}{|c|}{ Management Support } & $0.35 * * *$ & $0.34 * * *$ \\
\hline \multicolumn{2}{|c|}{ Competent Marketing \& PR } & $0.28 * *$ & $0.27 * *$ \\
\hline \multicolumn{2}{|c|}{ Weak Competitive Environment } & $0.28 * *$ & $0.22 * *$ \\
\hline \multicolumn{2}{|c|}{ Large \& Growing Market } & $0.27 * *$ & 0.16 \\
\hline \multirow{2}{*}{ Group Centroids } & Failure & -1.023 & -1.106 \\
\hline & Success & 0.943 & 0.968 \\
\hline \multicolumn{2}{|c|}{ Canonical Correlation } & 0.70 & 0.72 \\
\hline \multicolumn{2}{|c|}{ Eigenvalue: } & 0.978 & 1.100 \\
\hline \multicolumn{2}{|l|}{ Wilks' Lambda: } & $0.51 * *$ & $0.48 * *$ \\
\hline
\end{tabular}

$* \mathrm{p} \leq 0.05 ; * * \mathrm{p} \leq 0.01 ; * * * \mathrm{p} \leq 0.001$ 
Since the percent of the correct predictions was overestimated due to the use of the same cases in deriving the classification function, the analysis was rerun using half of the data to derive the function and the remainder to test the function's classification accuracy. All eight hypotheses were supported. $R \& D$ competence $\left(\mathrm{H}_{1}\right)$ was positively related to product/service success. When the R\&D group was competent and the product/service development was well planned, coordinated, and executed, the product/service was more likely to be financially successful. Marketing and PR competence $\left(\mathrm{H}_{2}\right)$ and management support $\left(\mathrm{H}_{3}\right)$ were also predictors of success. Product characteristics, product value $\left(\mathrm{H}_{4}\right)$ and technical superiority $\left(\mathrm{H}_{5}\right)$ were positively related to product success. Products that did not provide a significant value to the customer and products were more likely to be failures in this sample. Product and market choices were also important. Firms that built product and technology strengths $\left(\mathrm{H}_{6}\right)$ upon their existing market were more likely to have a product success. Finally, market characteristics also predicted the product outcome. Failures were more likely for products introduced into highly competitive $\left(\mathrm{H}_{7}\right)$, and small, stagnant markets $\left(\mathrm{H}_{8}\right)$.

Five major points arise from this study. The first key finding is that managerial excellence is critical to the product success. Products are more likely to be successful if they are planned and implemented well. Project planning should include all the phases of the development process, research, development, and market introduction. The functional groups should interact and coordinate activities during the development process. Particularly, important points are the links between R\&D and the other functional groups, marketing, and PR. One critical reason for a strong link with marketing is to ensure that the firm understands the user's needs and effectively translates these needs into solutions for the customer.

Second major conclusion is that new products must provide a significant value to the customer. Value can be measured in several ways. It can be a superior product/service performance or a characteristic of many of the successes in our sample. Value can be provided by a lower cost design, one that allows pricing the product lower than the competitive alternatives or it can also be provided by a product that provides a set of unique features. Superior product quality and reliability was another form of value for the customer.

The third primary contributor to the product success is the strategic focus. Firms should choose projects that build upon the firm's existing marketing, PR, and organizational competences. Related products allow firms to use and further develop the existing competences and take advantage of the communication sources and networks both internal and external to the firm.

Management commitment is also essential to the product success. Without management, support and capital resources necessary to develop the product are not likely to be approved. Securing the support of the management is materially aided if, early in the development process, the development team can demonstrate significant market demand for their product or service. Finally, the market environment is a contributor to the new product success. Products that are first to the market and experience little competition are more successful. In addition, introducing products into relatively large and growing markets is more likely to result in the product success. As the customer uses the new product, the developing firm must understand how customer needs change and mature, and then redesign the product accordingly. 


\section{Conclusion}

The example of medical companies that introduced a modern NPD and now have experience in this matter and run their business with success, shows that their decision was risky at first, but eventually right. They are not afraid of making the next move and extending the role of customers from passive observers (when they express their opinion only when they were directly asked about it) to active associates and decision makers.

During the one-year project, we have investigated over 300 medical products and services. We have conducted two surveys, numerous case studies and interviews with CEOs, and successfully developed and tested a model of new product development in medical businesses. The findings in this paper represent our understanding of the critical components affecting the successful launch of new products. We hope that these findings can be a guide to our further research as well as a useful source to those who are managing product development programs in different markets.

\section{References}

Brzeziński, M. (2001). Zarzadzanie innowacjami technicznymi i organizacyjnymi. Warszawa: Difin.

Dziadkiewicz, A., \& Kłos, M. (2013). Tworzenie zespołów różnorodnych w przedsiębiorstwach zorientowanych na design. Przedsiębiorczość i Zarządzanie, 16(12), 361-374.

Fuchs, C., \& Schreier, M. (2011). Customer empowerment in new product development. Journal of Product Innovation Management, 28(1), 17-32.

Gourville, J. T. (2006). Note on innovation diffusion: Rogers' five factors. Boston: Harvard Business School Background.

Kukian J. (2012). Innowacje $w$ zarzadzaniu produktem. Retrieved from http://www.pi.gov.pl/parp/chapter_86196.asp?soid=2754B4B0E1E147FFA484656A20E27065.

Pomykalski, A. (2001). Innowacje. Łódź: Politechnika Łódzka Publishing.

Rogers, E. M. (1962). Diffusion of Innovation ( $4^{\text {th }}$ ed.). New York: Free Press.

Ulwick, A. W. (2009). Czego chcą klienci? Tworzenie przełomowych produktów i usług dzięki innowacji ukierunkowanej na rezultaty. Warszawa: Oficyna a Wolters Kluwer Business. 